\title{
Modernizing the north: women, internal colonization and indigenous peoples
}

The IODE's most recent projects reflect an Anglo-Canadian identity which is much changed from what it had been in the early years of the twentieth century. The old racial categories have broken down, and new Canada-centered constructions of citizenship have emerged. Instead of concentrating on assimilating immigrants, the IODE has shifted focus, a shift that began during the Cold War, to a group of citizens who, although living within Canadian territory, were previously considered 'foreign'. This shift represented the change in Canada's identity from that of a dominion in the Empire, with an identity centred on Britain, to that of a nation situated in Canadian geographic space. The decreasing confidence in colonial attitudes was reflected in the drifting away of the IODE from involvement with the Canadian government towards the spaces of charity and the home. This chapter draws out the irony manifest in the attempt to assimilate indigenous peoples into the national project, and make them the same as other Canadians, while clinging to the spatial and social difference of the north. As this chapter shows, through the IODE's work in the Canadian north, this colonization took place within a national boundary.

\section{New horizons at home}

The Canadian north was the last region to which the IODE turned its attentions. The geographic isolation of the north, and its perceived low economic value, meant that for the first half of the century the IODE saw the north to be outside its vision of Canada. This is ironic, because as a nation Canada had already developed a mythical identity through its northern location. From the late nineteenth century, 'the true north strong and free' provided justification for the rhetoric of a robust and healthy nation. ${ }^{1}$ Yet no place was found in such rhetoric for the indigenous inhabitants, who were viewed as culturally backward and living in territories that were economically worthless. ${ }^{2}$ The north 
evoked by southern Canadians was a vast and harsh land, a masculine zone of heroes and explorers, of freedom of movement, of escape and confrontation with nature in the raw - a distant place having little in common with the rest of Canada. ${ }^{3}$

There have been two major phases of IODE work in the north. As far back as 1927, the IODE was involved in raising funds for the Quebecbased Labrador Voluntary Education League's provision of educational supplies and summer schools in the north. ${ }^{4}$ This work took place in the context of the undertakings of Grenfell in Labrador. ${ }^{5}$ It was not until the late 1950s, however, that the Order turned attention in a concerted way to the Northwest Territories and the Yukon. This was part of a shift that saw welfare extended to peoples in the north, with aid previously focused upon regions outside of Canada - such as Korea, India and Africa - moving back into Canadian territory. Where aid to India had operated during the first half of the century, in the post-Second World War years medical supplies and technology went to Korea and Africa, and considerable aid to postwar Europe.

Extending aid to the Canadian north was part of the territorial completion of Canadian nationalism during the 1940s and 1950s. This was the time of Diefenbaker's 'northern vision', whereby the Canadian Government reached out to encompass the north in a social-democratic welfare state. Newfoundland's and Labrador's entry into confederation, and the spread of social programmes into the north, were believed to be a part of Canada's manifest destiny. The move to aiding Canada was part of a nationwide recognition of socio-economic disparities previously downplayed in the education and health of Canadian citizens. At this time all indigenous Canadians were grouped as one people by the IODE, as was expressed in a 1960 recommendation to the Government to assist Canadian citizens of indigenous origin: 'The IODE feels that in a country which gives large scale aid to underdeveloped countries in many parts of the World, it is essential that a research programme be instituted immediately to ensure that our own citizens of Indian origin achieve equality of opportunity with the utmost speed..$^{6}$

Directly related to the push to assimilate and modernize indigenous peoples was Canada's new identity as a leading nation in international affairs. This identity was to be fostered by domestic good example and harmony. In the course of setting an example in human rights to other countries, on 19 January 1962 new immigration regulations were introduced that laid primary stress on education, training and skills as the criteria of admissibility to Canada, regardless of the country of origin of the applicant. Freda Hawkins has written that the new law was intended to remove racial discrimination as the major feature of 


\section{MODERNIZING THE NORTH}

Canada's immigration policy', and retained only one privilege for European immigrants over most non-Europeans in allowing them to sponsor a wider range of relatives. ${ }^{7}$ This change officially ended the preference for British immigrants. Minister for Immigration Ellen Fairclough stated that the new regulations represented 'a conscientious and sincere effort on the part of the Government of Canada to enshrine the principles of equity and justice which will guide responsible officials in the discharge of their difficult and complex duties'.

As Canada manoeuvred into a new position of strength on the world stage, its racist immigration policies were found to be an embarrassment. Ellen Fairclough was in fact a long-time IODE member who had held the national office for the immigration and citizenship division and had been prominent in the Ontario Provincial Chapter. It appears that, to Fairclough, Canada's world position was more important than such ingrained prejudice. She stated: 'it is my hope that the new immigration regulations will commend themselves to all members of parliament, regardless of party, to all Canadians and to prospective immigrants around the world'. Freda Hawkins has suggested that the pressure for the changes came from senior officials in Canada, including the deputy minister for immigration, who saw that Canada could not operate effectively within the United Nations or in a multi-racial Commonwealth 'with the millstone of a racially discriminatory immigration policy around her neck'. ${ }^{10}$

In keeping with tradition, the IODE responded to the new regulations by supporting government policy. In 1964, having had time to mull over the new regulations, the IODE stated: 'Canada respects the universal declaration of human rights of the United Nations which outlaws discrimination by reason of national origin. Therefore, it seems out of place for the Order at this time to advocate what might seem like a discriminatory immigration policy. ${ }^{11}$ So as to preserve the democratic traditions and institutions of Canada 'the Order might endorse a nondiscriminatory immigration policy and at the same time press for a more intensive programme of education for democratic citizenship among all Canadians, and particularly among immigrants ${ }^{\prime 12}$ The IODE was forced to reflect on its long-standing preference for British immigrants, notably its 1922 resolution: 'Now, 40 years later, insisting on a "preponderance of British citizens amongst those admitted to the country" means that we are in favour of admitting people from the West Indies, India, Pakistan and the Commonwealth Countries in preference to people from the Netherlands, Denmark, Germany etc. ${ }^{13}$ In the 1920s, when only a minority of the subjects of the British Empire were 'white', 'coloured' people were blocked from immigrating to Canada in large numbers, so that the preponderance of white migrants to Canada did not give rise to 
questions about racial preferment. In 1964, however, the situation was much changed. Putting the interests of the British Commonwealth second to those of Canada, the IODE was disturbed by the prospect of non-white British subjects migrating to Canada. As it still believed that those of 'white' and 'European' ethnicity were superior to 'coloured' Commonwealth citizens, Commonwealth attachments were weakened. Although the IODE officially supported government policy, unofficially there was much continuity with its earlier prejudices. The IODE was aware of the Canadian government's missions and posts throughout Western Europe, while there were 'almost no missions in the coloured countries'. ${ }^{14}$

In this context, immigration became of less importance to the IODE than it had been, and national identity became a more secure and important part of the IODE's representation of Canadian identity. By focusing on Canadian citizens themselves, and on the spaces of Canada from a North American geographical standpoint, the IODE focused more intensively on indigenous peoples, made a call for national unity, and gave more attention to French Canada, going so far as to note that 'at the present time in Canada there is a need for promoting national unity. Our policy of promoting British immigration over any other group could be construed as a slight to the French Canadians and people of other than British origin. ${ }^{15}$

This attention to French Canada was a response to the increasingly vocal call for the recognition of French Canadian distinctivness. Despite gestures by the IODE towards recognition of French Canada, change was slow. The IODE's neglect of the French language went unchecked until it began to risk embarrassment. In 1956, a draft letter from the Sherbrooke Municipal Chapter advised that the IODE would no longer be permitted to present naturalization greeting cards to new citizens in the courthouse unless they were printed in French as well as English. ${ }^{16}$ The IODE's national convenor for immigration and canadianization agreed with this stance and expressed surprise that the problem had not arisen before. She thought that if bilingual cards were printed, they should be available to all interested chapters. The convener stated that 'government literature is printed in both languages and I feel that the Order should do the same in this respect'. ${ }^{17}$ By 1975, however, some booklets were still being published in English only. The postmastergeneral's special assistant announced that the Post Office could not help the IODE with its work; a polite way of telling them that their booklet was no longer suitable, because chapters had been placing the IODE's English-only booklet 'How to become a Canadian citizen' in post offices.

In intervening in the north, the IODE was associated with the 


\section{MODERNIZING THE NORTH}

Canadian government's effort to increase its activities, and so its presence, there. Intertwined with ambitions for the social welfare of the indigenous peoples was a clear economic agenda. From the beginning of the IODE's intervention in the north, mention was made of the economic and resource potential of the Arctic. ${ }^{18}$ The IODE president stated in her opening speech at the 1959 National Meeting in Regina: 'The great mineral wealth of the Arctic is just beginning to be tapped. The Canadian Government is in the process of building roads to link strategic points and it is inevitable that communities will follow the industries as they are established. ${ }^{19}$

After the Second World War, the government and private companies looked with increased interest to the resource potential of the north, combining economic potential with welfare and defence objectives in the region. Tapping into the economic potential of the north was a useful way for Canada to increase its presence there, both to confirm sovereignty over the land and to make money. In an imperial context, if Canada did not step up its development of the Arctic, the country risked forfeiting its sovereignty claims to the Americans or, worse still, the Russians. Recalling the early IODE work in the north, one member commented in interview: 'I don't know if this has come to light in any of your studies, probably not. The Canadian government were worried about the Russians coming in. We were afraid that if we didn't work in the north we might lose that part of Canada. So the government wanted us up there. ${ }^{20}$

As argued in the previous chapter, the Cold War forced a new consideration of North American-situated defence concerns. In particular, the USA looked to the Canadian north, increasing its own presence there, building airbases and radar stations. In 1954 the Canadian Government decided to collaborate with the Americans to build the Distant Early Warning (DEW) Line, a system of radar-detecting stations, along the vast northern border at the 70th and 55th parallels, which would warn against long-range bomber attack. ${ }^{21}$ Figure 8.1 shows the line. The DEW Line went beyond defence in outreach, with economic and welfare objectives also involved. Mineral exploration and infrastructure were located near the lines, and it made sense to concentrate the requested welfare services in the same places. ${ }^{22}$ Such schemes had important implications for the people of the North. In 1955, an article in The Canadian Geographer contained the observation: 'the human geography of the Canadian Arctic is being rapidly recast' ${ }^{23}$ In the short run, the changes meant employment opportunities for indigenous peoples and, from another point of view, a new utility for people who had been seen as redundant. There were high hopes for the modernization and assimilation of native peoples. 


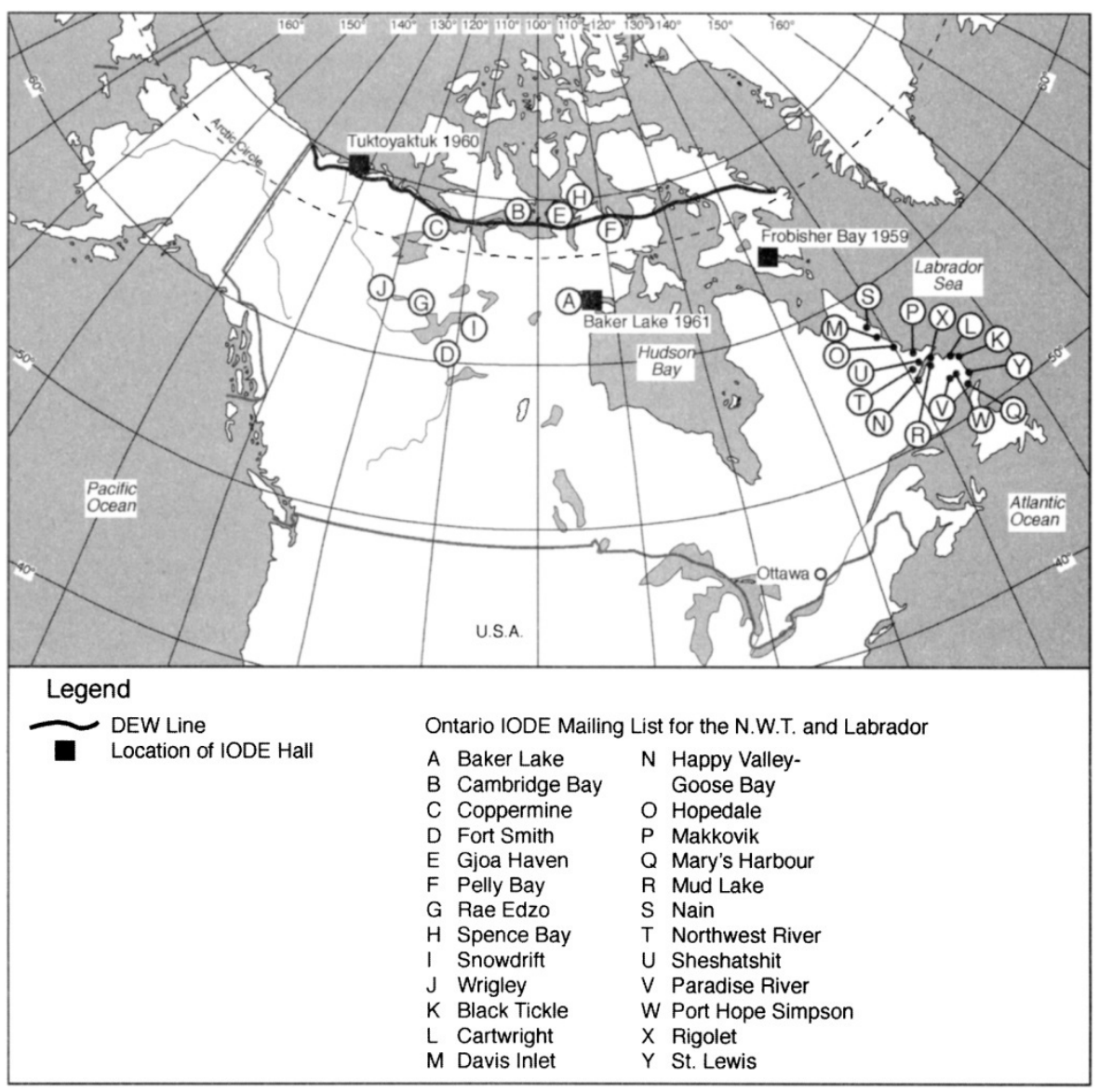

Figure 8.1 The IODE in the Canadian north (showing the DEW Line)

The IODE set itself the objective of helping northern peoples 'catch up' and become a part of Canada through entering the paid labour force. To 'enable them to fit into a competitive industrial life', the IODE president told the 1959 National Meeting in Regina, 'the Eskimos must, therefore, be provided with educational and vocational training', as it was noted that 'they have marked ability for anything mechanical and are readily absorbed into industry'. ${ }^{24}$ Resource extraction and the economic development of the north were seen as a wayout of starvation 
and appalling conditions, and there was a new feeling of goodwill towards a population perceived to be desperate. In 1959, for example, an article by an IODE member in Echoes, titled The Eskimo. His future is a challenge', claimed that 'the frontiers of civilization are pushing farther and farther northward, confronting the Eskimo with a new way of life, and he is going to require help in the process of adjustment ${ }^{\prime 25}$

Such intervention involved southern Canadians acting as guardians to indigenous peoples. They were treated as children, who needed to be brought up until they were old enough to look after themselves. ${ }^{26}$ The objective was to help indigenous people to escape from their 'primitive' conditions, made all the more harsh by their cold environment, to obliterate differences and make the north a part of Canada. There was little perception, however, of indigenous peoples as 'Canadians'. On the contrary, this 'development' was undertaken with much the same attitude as the IODE had demonstrated in its work in India and Africa. Likewise, as Tester and Kulchyski have argued, the government saw indigenous peoples as freakish 'artifacts', to be counted, marvelled at and relocated. ${ }^{27}$ None the less, such attitudes were a necessary part of the Canadian government's extension of social programmes into the north, appealing to a sense of improvement through intervention, as the socialdemocratic welfare state extended throughout Canada's diverse regions.

The first stage of the IODE's work was undertaken in direct consultation with government in line with the close cooperation typical of the IODE's long-standing relationship with the State. The work was surprisingly 'public sphere' in scope; that is, the IODE interacted in constructed public spaces with influential policy makers and was highly regarded by its colleagues. After members had attended a seminar on the 'Canadian Eskimo' in 1958, for instance, the IODE contacted the Federal Government to ask how it might help: 'We were told that while the Government was responsible for educational and welfare services, there were many other ways in which we could be of tremendous assistance. ${ }^{28}$ The Government suggested that the IODE build a community hall for the 'Eskimos' at Frobisher Bay, a fast-growing community of about 1,000 people. The plan was that the Government would provide a site, the 'Eskimos' would donate their labour and the IODE would pay the cost of materials of approximately $\$ 20,000$. In this pilot project the IODE considered itself to be the first women's organization to commence work in the Arctic. ${ }^{29}$ This claim was inaccurate, since women missionaries and church groups had long had a presence there, but as a Canadian patriotic order the IODE's presence, with citizenship at the heart of its operations, differed from that of a religious or benevolent organization. ${ }^{30}$ Like the donation of battleships, bombers and scholarships, the hall was 
a considerable undertaking and demonstrated the IODE's enduring strategic Empire-and nation-building concern.

At the IODE National Meeting in Regina in 1959 the Canadian Eskimo Fund was established, the community hall at Frobisher Bay being its first project. In her opening address to members, the president set out the need for economic and cultural change:

Conditions in the Arctic are changing in that the Caribou, which seven years ago were estimated to number 675,000, have decreased to approximately 200,000. A second great hardship is the decline in the price of furs. This situation, together with the fact that the frontiers of civilization are pushing farther and farther northward, is confronting the Eskimo with a new way of life, and he is going to require help from his fellow Canadians in adjusting himself to it. ${ }^{31}$

The message was that colonization was desirable and resistance was futile. It was inevitable that the north become a part of Canada and that northern people move beyond the harshness and deemed inadequacy of traditional ways.

So it was with a great sense of optimism that the building of the community hall at Frobisher Bay went ahead. In this project, the IODE was very much a part of the Government's relocation scheme for Inuit. The hall was located at Apex Hill, a new settlement on the DEW Line, five miles from the main centre of Frobisher Bay. Apex Hill was designated by the Government an 'Eskimo rehabilitation centre', a transitional housing centre for Eskimo families who were entering waged employment. ${ }^{32}$

The 1958-63 Canadian Eskimo Fund committee enjoyed an immediate accumulation of funds. The hall at Frobisher Bay was such a success that it was promptly followed by a hall at Tuktoyalctuk in 1960 and by another hall at Baker Lake in $1961 .^{33}$ Figure 8.1 shows the location of these halls. These buildings, also situated along the DEW Line, were similar in design and function to the Frobisher Bay hall. For the Tuktoyaktuk hall, the Government was to pay half the total cost according to the ratio of resident Inuit and non-Inuit. ${ }^{34}$ This worked out at 45 per cent.

The three community halls were visible schemes symbolic of Canadian community and togetherness. In building them, the IODE attempted to influence the culture of the Inuit, encouraging a sense of community that would promote the Inuit's sense of belonging to Canada. In 1962, Mrs Robinson, as national president of the IODE, visited the Arctic for two weeks and opened the Tuktoyaktuk hall. On her return, she told the Toronto Star: 'The hall has been given outright 
to the people up there. They can use it for their dances, for the showing of films, for anything they like. ${ }^{, 35}$ The 'anything they like', however, would preferably be the activities of Canadians of the south. Stereotypes concerning Inuit identity underpinned the hope for their adoption of 'southern' culture, such as western-style barn dances. It was noted in the records of the IODE Eskimo Fund in 1959 that 'the Eskimos, being a light-hearted people, have a flair for entertainment ${ }^{\prime}{ }^{36}$ In the north, the IODE asserted the symbols of its imagined Canada, deploying such markers in the landscape as the Union Jack and staff that were provided to the newly established Northwest Territories Court of Record in 1956, and in 1967 a Canadian flag to the Northwest Territories Court. ${ }^{37}$

Overall, there was an optimism about this first stage of work in the north. It occurred in a context of confident social welfare intervention and resource development, with the objectives of entrenching national sovereignty, serving the need to defend Canadian democracy against the perceived Communist threat and instituting the use of 'Eskimo' and 'Indian' as uncontested names. By 1969 little had changed in the perceived need for modernization and assimilation. In her president's report in 1969, Mrs Leggett made it clear that the north belonged to all Canadians and that IODE aid was seen as contributing to the extraction of wealth: "The North is a challenge to all Canadians. It is a rich land with great natural wealth. Canadians should realize this and ensure that these resources are developed for the benefit of all Canadians. ${ }^{38}$ To become 'useful and participating members of Canadian society', indigenous peoples, she said, would ideally be trained so that they might achieve 'equality of opportunity' by providing the labour force of the north. ${ }^{39}$

The perception of resource development and welfare as the keys to assimilating indigenous peoples into the living standards of the Canadian south persisted into the 1970s. In 1972, a report on 'Operation Help $\mathrm{Me}^{\prime}$ noted that the Inuit led a harsh life, with large groups starving to death in the 1950s as a consequence of being in a state of transition from their old ways of living to the use of new technology such as snowmobiles. ${ }^{40}$ The report went on to state: 'Eskimos are obviously caught between two ages, one with technology and one old and traditional. They cannot return to their old ways but they could receive assistance from modern technology', especially in radio communications. ${ }^{41}$

By the beginning of the 1970s, the initial IODE grand schemes had given way to more modest and localized health and education projects, where, making up for government underfunding, the IODE supplied the latest technology and other highly valued hospital equipment, especially 
X-ray machines and hearing aids. The provision of such equipment reinforced the identity of Canada as modern and progressive, even in the far reaches of the Canadian north. In supplying the most up-to-date equipment, the IODE forged ahead with its endeavour of modernizing the north and introducing new technology, while at the same time situating itself in the realm of feminine domesticity, providing aid to women and children. More and more, the IODE came to rely upon informal women's networks, which often operated through high social connections and direct collaboration with the wives of public servants. In 1973, for example, Mrs Michener, wife of the governor-general, after a discussion with Commissioner Stuart M. Hodgson of the Northwest Territories, suggested to the IODE that it provide hearing aids. ${ }^{42}$ Michener was also responsible for introducing infant incubators to the north.

\section{The focus on Labrador}

By 1977, many of the schemes initiated by the IODE had been taken over by the government, and IODE support was no longer as necessary in the north, particularly the Northwest Territories. So in 1979 the IODE turned to the second major phase of its work in the north: with the indigenous peoples of Labrador. There is no doubt that the work of the IODE in Labrador has been considerable, and it remains underpublicised. Especially in Ontario, Quebec and the Atlantic provinces, but all across Canada, IODE chapters have contributed to the many projects. It is estimated that more than $\$ 2$ million was raised and spent in Labrador between 1979 and 1993. ${ }^{43}$ Figure 8.1 maps the 1992 locations of aid to Labrador and the Northwest Territories from the IODE's Ontario provincial headquarters.

In this second phase of its work, the IODE's focus has been at the level of creating good future citizens in the form of native children. With its reliance on class-based informal networks maintained and reinforced, reminiscent of turn-of-the-twentieth-century philanthropists, IODE members worked mostly in the areas of education and health care. These emphases grew ever stronger as the IODE found itself still operating with awkward national and imperial ideals and, as a consequence, continued to retreat from more overt patriotic attempts into the 'feminine' spheres of care and nurture, of children in particular rather than of citizens in general. Deeper satisfaction was expressed about projects that gave 'boosts' to a variety of needs than was afforded by the highly visible hall building of the past. This change was summed up in the 1994 national president's comments regarding a new initiative with 
substance abusers: 'Now our "good works" are being channelled in a different direction. We are paving the way for a peer counselling program to help combat substance abuse in Labrador. If we can save the life of one child, if we can give one child renewed hope, our efforts will be rewarded. ${ }^{44}$ Gone was the language of tapping resource potential and fostering economic development. Instead talk was of 'good work,' individual hope, and charity. Such language was not unique at the time to the IODE. Other previously patriotic organizations, such as the Girl Guides and the YWCA, found themselves abandoning a rhetoric of imperialism in favour of one of inclusive community.

This change in scope is reflected in the re-presentation of the IODE's official status. Where in its beginning years the IODE had declared staunchly that it was a patriotic order and not a charitable or benevolent organization, it reversed its rhetoric. Today, the IODE is officially a charity, possessing a government-assigned charity number, and is somewhat fearful of being perceived as 'political' lest its status as a charity be taken away. Members today seem much more comfortable talking knitting and providing food for children than they do about the economic development of the north.

Whereas in the Northwest Territories education and welfare were areas of government intervention, in Labrador they increasingly became the responsibility of the IODE. Distant residential schools were no longer acceptable to either the Inuit or the Government, increasing the demand in local schools for IODE help. The IODE now has almost no direct contact with government; instead, it contacts individual teachers and nurses, asking them what their schools and hospitals need. Education is still seen by the IODE as an essential tool which the people of Labrador can use to improve their 'quality of life', the looser phrase now used in place of the emphasis on quickly becoming a part of Canada. Education is the key to becoming employable, and becoming employable is perceived as the way to a better life. In 1982 the IODE established a bursary to provide students from Labrador with funds for education in Canadian universities. It has also equipped an industrial arts room at Happy Valley-Goose Bay, a project that has served 'to help students stay in school and become employable ${ }^{45}$ In 1981, the IODE paid the air transportation costs of $\$ 6,000$ for approximately seventy students living in isolated villages to travel to a creative arts festival in Goose Bay. ${ }^{46}$ Music has also been encouraged, and instruments have been provided to encourage the formation of bands. As it has always fostered the education of girls, the IODE's work in the north has involved girls together with boys, although, obviously, within a context of gender-specific roles. While a focus on reading and writing was 
extended to both, the colours of hats probably did not challenge colours constructed as masculine and feminine.

In its work the IODE acts as a metaphorical godmother, sending its domestic goods to help colonize the north and make it a part of Canada. Chapters across Canada 'adopt' underfunded schools in Labrador and supply them with equipment. As one Quebec member said:

They don't have books to read, they need books. So what we do, in our chapter, is we send them books and magazines or we give them a new subscription to them, whatever they like. And for Christmas we send them favours, candies, and little chocolate Santa Clauses so that they can receive these things and have a little bit of Christmas, too, just like we have, because most of them are Inuit and they know nothing about having wonderful little parties. And we send them party hats. ${ }^{47}$

Because learning is not possible when children are cold and tired, the IODE prepares children for learning by providing food and clothing. The 'Snack-Pack Programme' in the schools of Labrador provides milk, juice, fruit and cheese. The same Quebec member describes how her chapter is occupied in providing clothing, and knitting slippers and tuque hats. Meanwhile, the Province of Ontario IODE operates a project called Footwear for Kids, where arrangements are made with different footwear manufacturers, and shipments of shoes are sent to different areas of Labrador. Socks also are provided. ${ }^{48}$ The material donated by the IODE is not solely domestic. A member recalls arriving, unannounced, by helicopter at the tiny village of Red Bay, where she saw a group of school children using a map, and others in the community using skates and skis, all sent by the IODE. ${ }^{49}$

\section{Female imperialism on the retreat}

The second phase of the IODE's work in Labrador is no longer in tune with government policy, and is moreover in a period of crisis and retreat. Overall, the Canadian north has not been assimilated to become a part of Canada as the IODE sees it. In a postcolonial climate of greater acceptance of difference and state promotion of multicul-turalism, the IODE's earlier vision for the Canadian north is outmoded. ${ }^{50}$ There is no longer a threat of a Russian invasion, and economic ventures are more the responsibility of private companies. Organized opposition by indigenous peoples has forced government to recognize that full assimilation is not possible, or desirable, as suggested by the 1988 Canadian Multiculturalism Act's recognition of Nunavit and omission of Inuit (Eskimo) peoples. ${ }^{51}$ 
The work of making the north a part of the south makes sense only as long as the north is recognized as different from the south. The more that members of the IODE perceive the north as changing to become like the south, the less needy the north appears. People in the cities and other regions of Canada are now perceived to be in just as much need as are those in the north. Because of this irony, it is necessary to selectively sustain the north as different. The irony of encouraging difference while seeking assimilation is apparent in the arts, where the IODE has selectively fostered Inuit arts, crafts and legends. The national headquarters of the IODE in Toronto and the provincial headquarters in Hamilton, Ontario, are testimony to the regard that the IODE has for indigenous art. Here tokens of appreciation from the north abound. There are moosehair flowers, soap stone carvings and quilts made by school children.

The tours of the north made by IODE members reinforce the perception of the north as a place of difference. Prominent IODE members have made trips to inspect the work in the north, and return south to report on this distant part of Canada. The early trips to the Northwest Territories were full of pomp and ceremony, as presidents of the IODE were received by politicians and governors-general. In trips to Labrador, in 1979, 1981, 1985, 1987, 1989 and 1993, there was a much greater attempt at 'hands-on' interaction. In interviews, the women who went on some of these trips recalled their great enthusiasm and determination: 'It was a thrilling experience of a lifetime', said one woman who went to Labrador in 1993. 'It was beautiful, majestic, glorious scenery. I still dream about it. It's so different. You can't imagine. ${ }^{52}$ Another woman, on a 1989 tour, gave her impressions of Mud Lake's community: 'Mud Lake is a beautiful little community with well-kept homes, a pretty little church, and a two-room school with a small teacherage attached. ${ }^{53}$ The general tidiness, and indicators of Christian worship and education, led her to report that all was well.

The 'othering' of the north has much to do with its geography. Whereas in the first stage of IODE work in the north the landscape was seen as contributing to the plight and desperation of northern peoples, now, despite its harsh climate, the landscape is perceived as beautiful. Positive images contribute to the romanticizing of the place and the people who live there. In contrast to an urban landscape of dirt and concrete, there is something awesome and inspirational in the vastness and severity of the north. A woman on a 1980 coastal tour of Labrador reported that at times she felt she was in 'another world'. ${ }^{54}$ Another woman observed: 'You really have to turn your head off, or turn it around, or do something. You can not judge normally. No, you can not. 
But it's fascinating to see. Oh, I find the people who've chosen to go there for their teaching career or a piece of their teaching career just marvellous. It's a different way of life there. ${ }^{55}$ There is a tendency to take a romantic, 'warm-fuzzy', view of the children. An IODE member who went to Labrador in the early 1980s said: 'But I like to think of the bright-eyed little kids of all kinds of funny mixed bloods and mixtures that I saw, wearing our boots or our mits, or having our breakfasts. ${ }^{56}$ Although the goal is to prevent 'Canadian' children from having to 'live like that in this land', ${ }^{57}$ real 'rescue' is no longer the objective of a diverse Canadian identity.

Through the 1990s romantic notions of the people and the land of the north were increasingly replaced by a vision of despair. Ironically, whereas the initial concern was with issues of national security and economic growth, now aid to adults has been abandoned, with efforts instead concentrated on individual children and youth in general. Said one member: 'The children are beautiful. They have so little opportunity. Their traditional way of life and values have been destroyed. I'm dubious of a way out. They can't go back. It's a tragic situation. I hope they can be helped. ${ }^{58}$

For some women of the IODE today, the north remains an almost mythical landscape of difference, despair and degradation. Thousands of women, especially in Ontario, continue to knit. They make garments for people they may never meet, but they feel a great sense of motivation to give to children they think of as 'the needy':

We give them things to wear on their heads to keep them warm. Scarves, we're always knitting. Every night when I'm watching television - we never stop. Now, if I'm too tired, I don't knit. But if I'm wide awake, like I am now, I'll probably be knitting tonight. They [the garments]don't take long. Stuff to keep their hands warm. Something that they can pull down under their ears, because it's cold there in Labrador. Now we have to make the strong fentex-type slippers - something that doesn't wear out. ${ }^{59}$

Change is not happening to the extent that was desired, and the IODE is silent with respect to new self-governed territories and pending land claims. ${ }^{60}$ 'You can't do much for these people' is what some members now believe, ${ }^{61}$ and IODE help is seen by them as 'just another drop in the bucket', consisting of 'band aid solutions'. 'I hope they can change. It [the way of life] goes right back in their culture'. ${ }^{62}$ 'They were living in tents, not houses until the 1950s. Now they're being brought into the twentieth century. ${ }^{63}$ A member in Saskatchewan expressed her sense of hopelessness in these words: 'But, you know, all of this talk about Davis Inlet. Substance abuse and all that. People don't realize the IODE was in there doing work long before this came out. So it's not because we 
haven't tried. And there's problems in some of those places that no volunteer organization is ever gonna solve. We can try, but really ...' ${ }^{64}$ The IODE's present lack of confidence in its work does not mean that the Order should be considered of little importance to the postwar history of the Canadian north. The IODE has skilfully utilized its identity as a voluntary group of affluent Anglo-Celtic women in going about its work. But the ideology behind the work is now old-fashioned and inappropriate to the demands of indigenous Canadians.

It is not just in the north that the IODE has faced crisis and retreat. Its citizenship work more generally has come under increasing challenge. Professionals are now employed as interpreters and government services provide English lessons. As the structure of citizenship courts changes, erosion of the IODE presence has varied from place to place according to the local actors. In New Brunswick the IODE no longer participates in the way that it used to: 'We always gave little welcome cards, Canadian flag pins or maple leafs. And they asked us not to do that anymore. In fact we find more and more that the government is taking over things like that. ${ }^{65}$ In general, the organization is no longer welcome or relevant at courts, except to provide food and refreshments. ${ }^{66}$ The food that was so essential at the ports in the 1920s is now incidental at the courts. In Saskatchewan members still hold receptions and serve lunches, ${ }^{67}$ and in 1994 British Columbia members served 170 cookies at one such reception, ${ }^{68}$ but the days of handing out patriotic literature and gifts are drawing to a close.

The structure of the courts has changed over the last twenty years, adapting to demands for less ceremony, more vigorous cost-cutting, and the emphasis on multiculturalism. In 1993 the Government announced a plan to terminate the system of patronage under which citizenship court judges were appointed. A Saskatchewan member laments the day she heard about this change, and her spontaneous comment reflects the complexity and ambiguity of the IODE's work with immigrants, its backward and its forward look:

I didn't hear all of this until this morning. This is where I said yesterday, let's get on that bandwagon. We had a citizenship court judge as our guest speaker at our banquet, and she had tears in her eyes when she heard. Now they're talking about doing away with the patronage and the amount of money that they're paying for these judges. But when they appointed these judges, we liked the system as it was before. We were very involved with teaching English in a lot of cases, helping [immigrants] with their questions, their rights and responsibilities, all of this. We were there for them, at every session, and often we would take them aside to make sure that they knew things. Well that's all at an end. The judges just sat down and talked to them. We never quite knew what the judge was saying, and what was 
happening and what they knew to become Canadian citizens, and now it's going to be even less. They're going to be able to slip into this country as just anybody, and it's time for us to get on the bandwagon for this and say 'This isn't good enough.' But we'll be called radical. But why not be radical if we believe in something? ${ }^{69}$

The call to be radical in the face of a diminishing presence is not carried through to the IODE's official position. Gone are the days of the IODE proudly sharing its opinions on Canada and the Empire at citizenship courts, and its part in confidently combining capitalism, culture and imperialism with the objective of making the north a part of Canada is much diminished. As one contemporary member commented on the contact that members have through letters and photos from their 'adoptees' in the north: 'And it's wonderful, the contact. We had a marvellous teacher not too long ago, and she sent us a video all about the children. It was so much fun to see them out in the snow and everything, so this work is helping another area of the World - well of our own country. ${ }^{70}$ Such paradox and tension between national and imperial identities capture the IODE's complicated and shifting endeavours to make the north a part of Canada. In contemporary times, the IODE is confronted with a national climate in which the greater acceptance of difference challenges its ideas of citizenship; and, as its members age, the IODE is now attempting to colonize the north through individual patronage and domestic methods - a far cry from its earlier involvement in the sweeping momentum of governmental initiatives. The objective of making the north a part of Canada remains incomplete, contradictory and fragmented, a state of affairs indicative of the eclipsing of an imperial ideology by a diverse Canadian national identity. A vital part of this new diversity is that indigenous peoples have gained more agency, and the right to autonomy, rendering the IODE marginal.

\section{Notes}

1 Carl Berger, 'The true north strong and free', in Peter Russell (ed.), Nationalism in Canada (Toronto: University of Toronto Press, 1966), 3-26.

2 See R. Quinn Duffy, The Road to Nunavut: The Progress of the Eastern Arctic Inuit Since the Second World War (Montreal and Kingston: McGill-Queen's University Press, 1988).

3 Carl Berger, 'The true north strong and free'; Lisa Bloom, Gender on Ice: American Ideologies of Polar Expeditions (Minneapolis and London: University of Minnesota Press, 1993).

4 Echoes (1930), 11 and 15; Echoes, 150 (1938), 10.

5 Ronald Rompkey, Grenfell of Labrador: A Biography (Toronto: University of Toronto Press, 1991).

6 NAC MG28 I 17, no date, Canadian Eskimo Fund, 1959-63. 
7 NAC MG28 I 17, loose document. Ellen Fairclough, 1962 Regulations and Statement, 1. Freda Hawkins, Critical Years in Immigration: Canada and Australia Compared (Kingston and Montreal: McGill-Queen's University Press, 1989), 39.

8 Ibid., 7.

9 Ibid., 6.

10 Hawkins, Critical Years in Immigration, 39.

11 NAC MG28 I 17, 9, 1, 4 March 1964.

12 Ibid.

13 Ibid.

14 Ibid.

15 Ibid.

16 NAC MG28 I 17, 8, 5 September 1956.

17 Ibid.

18 NAC MG28 I 17, 26, 2, 1959.

19 Ibid.

20 Interview, 4 November 1994: Ottawa, Ontario.

21 Peter J. Usher, The north: metropolitan frontier, native homeland? ${ }^{7}$, in L. D. McCann (ed.), A Geography of Canada. Heartland and Hinterland (Scarborough, Ontario: Prentice-Hall, 1982), 411-56, at 429. The DEW line was a combined USA-Canada project. There would be radar-detecting stations crossing from Alaska to the central Canadian Arctic to Baffin Island at the 70th parallel and a radar line at the 55th parallel.

22 The McGill sub-Arctic research station opened in Schefferville in 1955. It was funded by the Canadian Defence Research Board and the mining and construction companies involved in the development of local iron-ore deposits. John T. Parry, 'Geomorphology in Canada', The Canadian Geographer, 11: 4 (1967), 280-311, at 292. Situated on the 55th parallel, it was the location or a new airstrip, and radar and weather equipment. Two native bands were relocated to the area.

23 G. H. Michie and E. M. Neil, 'Cultural conflict in the Canadian Arctic', The Canadian Geographer, 5 (1955), 22-41, at 41.

24 NAC MG28 I 17, 26, 2, 1959.

25 'The Eskimo - his future is a challenge', Echoes, 236 (autumn 1959), 6.

26 Quinn Duffy, The Road to Nunavut, xxiii.

27 See Frank J. Tester and Peter Kulchyski, Tamarniit (Mistakes): Innuit Relocation in the Eastern Arctic, 1939-63 (Vancouver: University of British Columbia Press, 1994).

28 NAC MG28 I 17, 14, Minutes of the Eskimo affairs committee.

29 Ibid.

30 NAC MG28 I 17, no date, Canadian Eskimo Fund, 1959-1963. The Women's Auxiliary had been helping since the 1920s and there had also been women's missionary work in the Arctic.

31 NAC MG28 I 17, 26, 2.

32 Quinn Duffy, The Road to Nunavut, 30.

33 Echoes, 240 (autumn 1960).

34 Ibid. This worked out at 45 per cent.

35 Toronto Star, 13 December 1962.

36 NAC MG28 I 17, 8, 5 November 1959, Eskimo Fund Frobisher Bay, 315.

37 May Kertland, IODE. The Third Twenty-Five Years (Toronto: G. Best Publishing), 1975.

38 NAC MG28 I 17, 13, 2, 14, 1969.

39 Ibid.

40 NAC MG28 I 17, 26, 1, Operation 'Help Me' typed July 1972.

41 Ibid. 
42 St Thomas Times (Ontario), 19 June 1973.

43 National headquarters IODE, unpublished 1993 IODE report.

44 Echoes, 359 (1993-94), 4.

45 Echoes, 358 (1993), 1.

46 Echoes, 326 (1982), 16.

47 Interview, 22 November 1993: Montreal, Quebec.

48 Interview, 4 November 1994: Ottawa, Ontario.

49 Interview, 25 February 1994: Toronto, Ontario.

50 For a discussion of multiculturalism see Audrey Kobayashi, 'Multiculturalism: representing a Canadian institution', in James Duncan and David Ley (eds), Place/Culture/Representation (London and New York: Routledge, 1993), 205-31.

51 Section 2 of the 1988 Canadian Multiculturalism Act states: 'The Yukon and the Northwest Territories as well as Indian bands and band councils, are excluded from the application of the Act in compliance with the ongoing process of delegation of powers by the Government of Canada.' The Canadian Multiculturalism Act (Ottawa: Government Printer, 1988).

52 First interview, 24 February 1994: Toronto, Ontario.

53 Jean Throope, Echoes, 348 (1989-90), 6.

54 Echoes, $317(1980), 6$.

55 First interview, 24 February 1994: Toronto, Ontario.

56 Interview, 25 February 1994: Toronto, Ontario.

57 First interview, 24 February 1994: Toronto, Ontario.

58 Ibid.

59 Interview, November 1993: Montreal, Quebec. The interviewee is referring to a class of 9-year-olds 'adopted' by her chapter.

60 Ken Coates (ed.), Aboriginal Land Claims in Canada: A Regional Perspective (Toronto: Copp Clark Pitman, 1992).

61 Interview, 14 July 1993: St John's, Newfoundland.

62 Second interview, 24 February 1994: Toronto, Ontario.

63 First interview, 24 February 1994: Toronto, Ontario.

64 Interview, 20 April 1994: Meota, Saskatchewan.

65 Interview, 25 October 1993: Saint John, New Brunswick.

66 Interview, 25 February 1994: Toronto, Ontario.

67 Interview, 18 April 1994: Regina, Saskatchewan.

68 Interview, 29 April 1994: Vancouver, British Columbia.

69 Interview, 17 April 1994: Regina, Saskatchewan.

70 Interview, 4 November 1993: Ottawa, Ontario. 